\title{
AN INNOVATIVE COST MODELLING SYSTEM TO SUPPORT LEAN PRODUCT AND PROCESS DEVELOPMENT
}

\author{
Ahmad Wasim ${ }^{1}$, Essam Shehab ${ }^{1}$, Hassan Abdalla ${ }^{2}$, Ahmed Al-Ashaab ${ }^{1}$, Robert Sulowski ${ }^{3}$, \\ Rahman Alam ${ }^{1}$ \\ ${ }^{1}$ Product and Service Innovation Centre, Manufacturing and Materials Department, Cranfield University, \\ Cranfield, Bedford, MK43 0AL, UK \\ ${ }^{2}$ School of Architecture, Computing and Engineering, University of East London, London, UK \\ ${ }^{3}$ SITECH Sp. So. o. Poland \\ e.shehab@cranfield.ac.uk
}

\begin{abstract}
This paper presents a cost modelling system for lean product and process development to support proactive decision making and mistake elimination at the design stage. The foundations of the system are based upon three lean product and process development enablers, namely: Set-Based Concurrent Engineering, Knowledge-based Engineering, and mistake proofing (Poka-yoke). The development commenced with an industrial field study of eleven leading European industries from the aerospace, automotive, telecommunication, medical and domestic appliance sectors. Based on the requirements of industrial collaborators, the developed system comprises six modules: value identification, manufacturing process / machines selection, material selection, geometric features specification, geometric features and manufacturability assessment, and manufacturing time and cost estimation. The work involved the development of a feature-based cost estimation method for the resistance spot welding process. The developed system was finally validated using an industrial case study.
\end{abstract}

The developed system has the capability to provide estimates related to product cost and associated values concurrently, facilitate decision making, eliminate mistakes during the design stage, and incorporate 'customer voice' during a critical decision making stage.

Key words: Lean product development; Cost Modelling; Set-Based Concurrent Engineering; Knowledge-based Engineering; Mistake proofing (Poka-yoke). 


\section{INTRODUCTION}

Current socio-technical effects of global competition have forced companies to develop additional competitive product development strategies in order to deliver more innovative products that meet customer expectations in a shorter lead time, with less cost, high quality, and a quick response to market changes. Since $70 \%$ of product cost is committed in the design phase (Shehab and Abdalla, 2001); the product development team therefore considers this phase critically and puts special measures in place to avoid mistakes or unforeseen circumstances that could cause a hindrance to the successful manufacture of artefacts.

One of the current measures used by industry is to equip designers with cost estimation capabilities which allow for manufacturing cost estimation during the design phase. Some of cost estimation systems discussed in literature include those of Bouaziz et al. (2006); Chayoukhi et al. (2009); Cicconi et al. (2010); Masmoudi et al. (2007); Quintana and Ciurana (2011); and Shehab and Abdalla (2002b). These systems focus on providing manufacturing cost estimations for designers. It is worth stating that in such a dynamic environment, where the customer demands and needs are constantly changing, companies need to adhere to this change by capturing and channelling customer requirements into their product design process. Therefore, a cost estimation system should be capable of supporting designers to optimise manufacturing cost while considering other important factors such as manufacturing time, product quality, crash strength, etc. Incorporating a lean thinking approach into the cost estimation system will overcome limitations in previously developed systems. Lean thinking is a philosophy that aims to both enhance value and reduce waste. Lean manufacturing and lean enterprise have been developed for the shop floor and top management respectively. Today, researchers and practitioners are striving to develop principles, models and methodologies for lean product and process development (Kennedy et al., 2008; Mascitelli, 2004; Morgan and Liker, 2006; Sobek and Liker, 1998; Sobek et al., 1999; Ward, 2007).

Cranfield University is leading a LeanPPD (Lean Product and Process Development) project which is funded by the European Union (EU-FP7) (www.leanppd.eu). The project aims to 
develop a new model for European companies which goes beyond lean manufacturing to ensure the transformation of enterprise into lean environment (Al-Ashaab et al., 2010).

This research work investigates aspects related to the LeanPPD (Lean Product and Process Development) project which aims to develop a new cost model of manufacturing cost estimation that enables designers to take the right decisions and avoid mistakes at the product development design stage. This paper has been structured as follows; Section 2 outlines the literature review of research conducted in the areas of lean product and process development, and cost estimation systems. Section 3 describes the research methodology. Section 4 presents the developed system. Section 5 explains the system scenario; whereas, the system implementation and benefits are outlined in Section 6. The system validation is presented in Section 7. Finally, the overall conclusions are discussed in Section 8.

\section{RELATED WORK}

Lean product and process development is a systematic approach to the development of products and their associated production processes in a knowledge-based continuous improvement environment, which focuses on the creation of value, and results in the reduction of waste. This is achieved through enhancing a stream of activities, so that decisions are made based on acquired knowledge. Lean product and process development encompasses a number of enablers or building blocks (Al-Ashaab et al., 2010; Khan et al., 2011b); however, this research work deals with only three enablers, namely Set-Based Concurrent Engineering, Knowledge-based Engineering, and mistake proofing (Poka-yoke). These enablers have been chosen carefully after a literature review and field study. Only those enablers which have a major impact on lean product and process development have been selected; and also have the potential to be adopted into a cost estimation system.

Set-Based Concurrent Engineering is the process of exploring alternative ideas by considering a set of design space instead of a single design solution (Morgan and Liker, 2006; Sobek et al., 1999; Ward, 2007). In this method, designers communicate explicitly to develop sets of design solutions on the basis of their preferences. As the design progresses, they eliminate the inferior sets of design to narrow down the design space and finally reach a single acceptable solution 
(Khan et al., 2011a; Ward, 2007). Set-Based Concurrent Engineering includes a number of tools namely checklists, trade-off curves, and a matrix for communicating alternatives. Checklists are employed to reduce the conflict and mistakes among functional teams, trade-off curves are used to support design optimisation through visualisation, and the matrix for communicating alternatives is applicable to sort out alternative designs through conversation with all stakeholders (Sobek et al., 1999). Set-Based Concurrent Engineering has a number of advantages; for example, it helps to identify more design solutions, reduces communication requirement with suppliers, improves concurrency in functional departments, eliminates work delays and increases trust in working relationships (Ward et al., 1995).

Knowledge-based engineering is the use of advanced dedicated software tools to capture (acquire) and re-use product and process engineering knowledge (Curran et al., 2009; Skarka, 2007; Stokes, 2001). Knowledge is represented in a variety of forms including object oriented, trees, rules, frames, semantic networks, procedural knowledge, logic and statistical knowledge (Tammineni et al., 2009). Lean product and process development emphasises creating a knowledge-based continuous improvement environment for surviving and growing faster than competitors (Morgan and Liker, 2006). This environment is developed through several ideals such as checklists, quality matrices, learning focus problem solving, hansei events, and a knowhow database. The checklist is one of the more widely applicable tools, maintained to identify feasible design space, remove the conflict between functional groups and identify the product manufacturability (Sobek et al., 1999; Ward et al., 1995). Checklists include functionality (e.g., minimum acceptable sheet thickness for laser welding), manufacturability (e.g., capability of the lathe machine to turn the specific component at the required surface speed), government regulation, and reliability (Sobek et al., 1999).

Mistake proofing (Poka-yoke) has evolved from lean manufacturing. Its objective is to avoid the passing of defective product downstream and eliminate the risk that undetected defects end up in the customer's hand (Kremer and Fabrizio, 2005). Jamaludin (2008) defines mistake proofing as a device or practice that aims to prevent the error causing the defects. Mistake proofing has a number of advantages, i.e. it reduces the redesign, rework and repair requirements; removes the 
inspections necessity; minimises the defect rates; and reduces lengthy documentation (Mital et al., 2008).

Cost in the product development design phase is estimated using two different methods, i.e. design-for-cost and design-to-cost (Shehab and Abdalla, 2001). In the former, engineering processes are used to reduce the life cycle cost of a product; whereas in the latter, the design is required to satisfy certain identified cost targets. Traditionally, there are two types of cost estimation methods; first sight cost estimate, and detailed cost estimate (Roy, 2003). In the first method, a considerable amount of experience is mandatory to have an accurate cost; whereas, the second method requires a substantial amount of data. Shehab and Abdalla (2001) classified the cost estimation methods as intuitive, parametric, analogical and analytical. The selection of a suitable cost estimation method is considered to be a very difficult job. It depends on data availability, estimator's experience and the required precision level of estimation Therefore, Niazi et al. (2006) categorise cost estimation methods based on qualitative and quantitative data. Qualitative methods are applicable at the early stage of product design and for a rough estimate, since a limited amount of data is available in this stage. Quantitative methods on the other hand, are suitable for detailed estimation because of the large amount of data available.

A number of initiatives have been taken by several authors to develop the methods and systems for estimating the manufacturing cost during early design stage; however, most of these systems are concerned with cost estimation without considering lean product and process development. Although they do consider some aspects of lean product and process development enablers, they do not, however, follow the lean principles. Furthermore, most of these systems employ either single or only two enablers; therefore, the advantages of their combined effects are still unforeseen. For example, Feng and Zhang (1999) developed a method of manufacturing cost estimation. The key focus is manufacturability identification in order to eliminate mistakes in estimation. Chan and Lewis (2000), and Shehab and Abdalla (2002b) developed a knowledgebased system to estimate product cost. The system provides decision making support related to material and manufacturing processes selection. The knowledge-based cost estimation system developed by Bouaziz et al. (2006) helps to decrease the estimation time, and to improve the quality of estimation by removing uncertainties. Masmoudi et al. (2007) and Chayoukhi et al. 
(2009) developed welding cost estimation systems to compare the cost of alternative welding processes. Mauchand et al. (2008) proposed a knowledge-based system to assist product designers in estimating the manufacturing cost at the conceptual design stage. Cost reduction and optimum requirement achievements are the main objectives of the proposed tool. The cost estimation system developed by Quintana and Ciurana (2011) facilitates the selection of a suitable manufacturing process on the basis of product and machine characteristics.

\subsection{Limitations of existing cost methods and models}

1. As previously explained, cost estimation systems and models apply to either design-for-cost or design-to-cost (Shehab and Abdalla, 2001). In either case, previously developed methods and models are highly recommendable if the targets are achieved with one proposed design. However, the same method becomes entirely distorted with a higher number of revisions.

2. A number of developed systems and models provide a decision making support related to material and manufacturing processes selection (Chayoukhi et al., 2009; Djassemi, 2008; Er and Dias, 2000; Esawi and Ashby, 2003; Mauchand et al., 2008). However, the decisions are based only on cost, whereas other product values such as product weight, quality, and performance are mostly ignored. In other words, direct or indirect customer values are ignored in the decision making process.

3. Although previously developed systems help designers to compare alternative designs (Chan, 2003; Shehab and Abdalla, 2002a, 2002b), they do not propose the best design option. Solution conversion is one of the key steps in the set-based concurrent engineering process, as it focuses on eliminating the weak solution. In the conceptual design stage, the number of meetings held to finalise the design option can be minimised if a method is provided to designers that help them to identify the strongest solution.

4. Inappropriate assumptions at the conceptual design stage lead to incorrect cost estimates, which may lead to higher development costs and loss of market share. Although a number of authors (Chan, 2003; Feng and Zhang, 1999; Ou-Yang and Lin, 1997) focus on product manufacturability identification at the early design stage, these systems do not highlight the importance of analysing the companies' current manufacturing capabilities. In addition, these systems do not take into consideration the mistakes which could be made by designers. 
By identifying these errors at the design stage, there is the possibility of developing precise estimates along with a fool-proof design.

The current literature on lean product and process development indicates that Set-Based Concurrent Engineering, Knowledge-based Engineering, and mistake proofing (Poka-yoke) are important lean enablers that support the feasibility and identification of design space, remove conflict among functional groups, and eradicate errors in a knowledge-based environment. Additionally, literature on manufacturing cost estimation highlights that the main tendency focuses on supporting designers during conceptualisation without taking into consideration lean product and process development principles. Although, they may apply instances of Knowledgebased Engineering; however, other supporting lean enablers such as Set-Based Concurrent Engineering, and mistake proofing (Poka-yoke) should be incorporated into cost estimation. In identifying this research potential, a cost modelling system for lean product and process development has been developed in order to address the shortcomings of current cost estimation systems.

\section{RESEARCH METHODOLOGY}

The research methodology is composed of four phases, as presented in Figure 1. It commenced with understanding cost estimation within lean product and process development. A literature survey was performed on manufacturing cost estimation at the design phase, and philosophy and current findings on lean product and process development. The survey results identified enablers for both cost estimation systems, and lean product and process development, as explained in section 2. The key focus in phase 2 was the identification of industrial cost estimation practices and challenges. For this purpose, a field study was carried out with eleven different European industries including aerospace, automotive, telecommunication, medical and domestic appliances. A total number of 40 face to face interviews via semi structured questionnaires and focus groups were carried out to identify the current industrial practices. The findings were used to establish the foundations for developing a more tangible cost estimation system. A cost modelling system for lean product and process development was developed in phase 3 . The system was further refined through feedback from industrial collaborators within the LeanPPD project. The system was developed in C\# 3.0 within .NET Framework and Microsoft SQL Server 
2008. Finally the validation of the system was carried out using an industrial case study, as presented in phase 4.

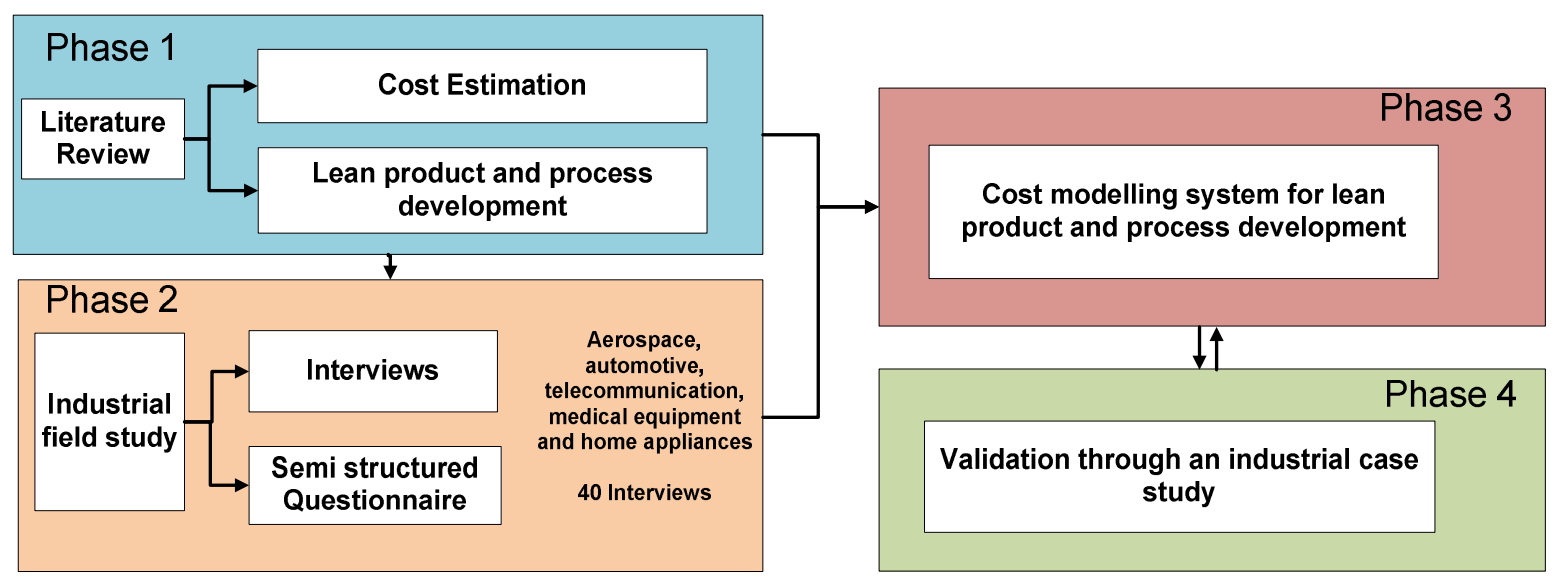

Figure 1: Research methodology

\section{THE DEVELOPED SYSTEM}

The developed system provides a number of design values for designers to promote more accurate decisions during the concept generation stage. Applying Poka-yoke principles, it further enhances the design by reducing design mistakes through predefined assessment criteria. Additionally the system has been developed to allow for the selection of the most adequate materials and manufacturing processes. The overall architecture of the developed system consists of a set of lean enablers, six modules, a user interface, and a CAD solid modelling system, as shown in Figure 2. Further descriptions of the system components are outlined below.

\subsection{Lean enablers}

\subsubsection{Knowledge-based Engineering for cost estimation system}

A hybrid knowledge representation technique was implemented for the development of the knowledge-based system for costing. Furthermore, both an object oriented and a rule-based system were applied for material and associated values identification, manufacturing process/machine selection, manufacturing cost estimation and process parameters generation. Examples of these rules are shown below: 


\section{Material and related properties identification rule}

If

(The component required hardness is $75 \mathrm{Bhn}$ )

AND

(The component density is $2.67 \times 10^{3}$ )

AND

(Additional rule)

Then

(Material MAT-AL\$ is selected)

(Selected material thermal conductivity is $205 \mathrm{~W} / \mathrm{mK}$ )

(Selected material tensile strength is $76 \mathrm{MPa}$ )

(Selected material maximum service temperature is $130^{\circ} \mathrm{C}$ )

(Selected material minimum service temperature is $-273^{\circ} \mathrm{C}$ )

(Additional rule)

Where MAT-AL $\$$ is Aluminium alloys (cast)

\section{User Interface}

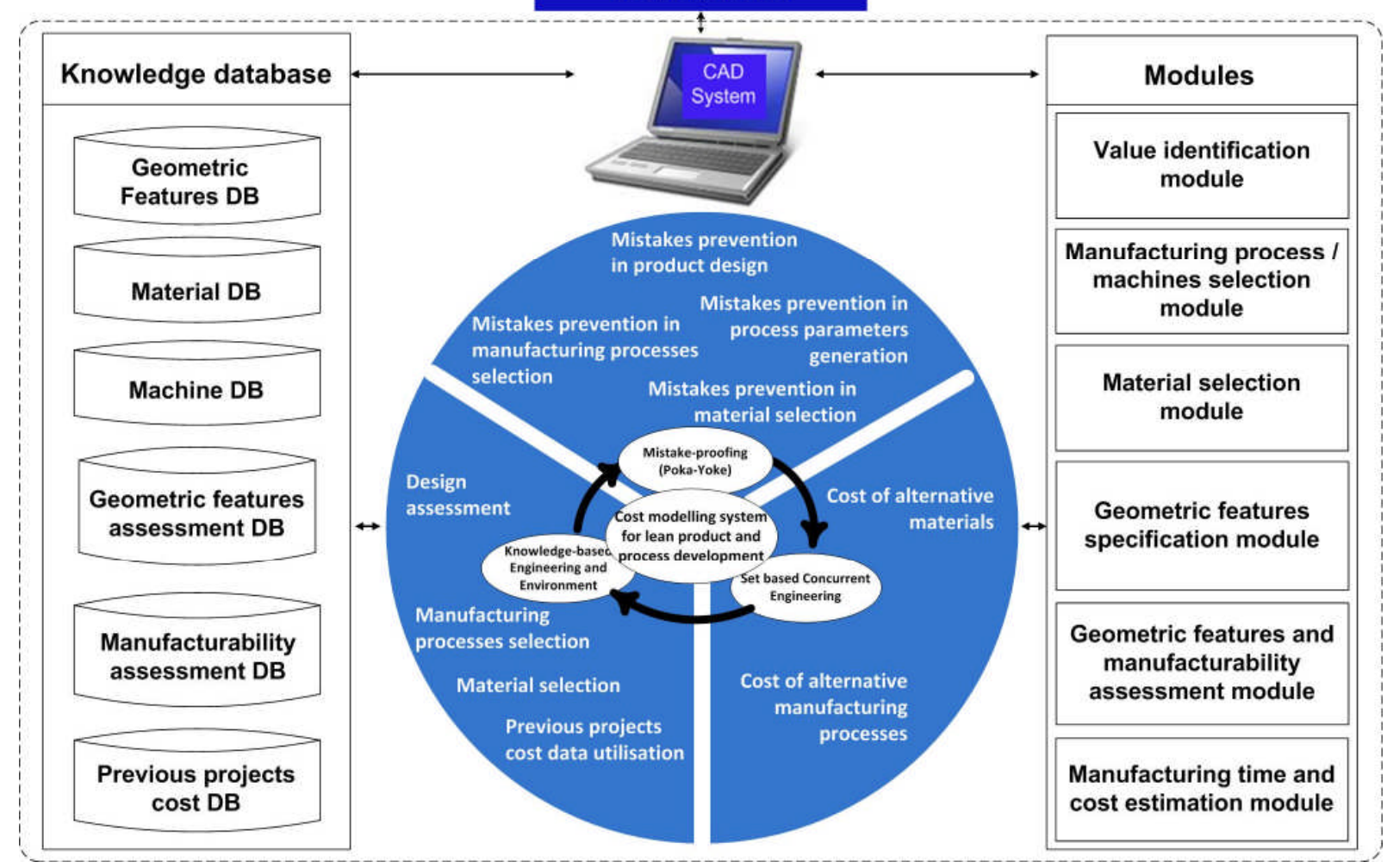

Figure 2: Architecture of the developed system 


\section{Manufacturing process selection rule}

If

(The component material is Low Carbon Steel)

AND

(The part feature is a hole)

AND

(The diameter of the hole is $<=3 \mathrm{~mm}$ )

AND

(The tolerance of the hole $<=0.005 \mathrm{~mm}$ )

AND

(Additional rule)

Then

(D001 and M005 are suitable machines available in the manufacturing facility)

D001 is a drilling machine and M005 is a CNC milling machine

\section{Process parameters generation rule}

If

(The component material is low carbon steel)

AND

(The part thickness is $0.51 \mathrm{~mm}$ )

AND

(Machine selected is resistance spot welding)

AND

(Additional rule)

Then

(Weld current is $8.51 \mathrm{~A}$ )

AND

(Weld time is 7 cycles)

AND

(Hold time is 7 cycles)

AND

(Squeeze time is 7 cycles)

\subsubsection{Set-Based Concurrent Engineering}

During the development of the system, a systematic Set-Based Concurrent method was taken into consideration. In addition, a method to eliminate any weak solution was proposed. The SetBased Concurrent Engineering method includes: (i) explore customer and company values and give them preferences; (ii) identify the target of each value through experts' judgement, past experience, analysis, experimentation and/or testing; (iii) develop multiple alternative solutions concurrently; (iv) apply minimum constraints to find the compatibility of alternatives, and finally (v) narrow down the alternatives gradually to reach the final solution. 
In the first step of a Set-Based Concurrent Engineering method, the designer must be aware of customer and company values, and their preferences. The system has the capability to generate the estimates for nine values, namely product cost, manufacturing time, production volume, product weight, product hardness, thermal conductivity, maximum service temperature, minimum service temperature, and tensile strength. Designers are required to assign a preference from 1 to 10 for each value.

In the second step, the designer is required to input the targets against each value. For example, if the crash strength of the final product is greater than $75(\mathrm{MPa})$, then the proposed material is an excellent option; however, if the crash strength is less than 50 (MPa), then the proposed material will be unacceptable and therefore rejected.

In the system, four target ranges were set into the system, namely excellent, acceptable, marginal and unacceptable. Each target range is denoted by a special graphical visual and target intermediator (Table 1). The target intermediator is simply a conversion number, which has been introduced here to compare targets with estimated results. For example, if the estimated result of crash strength is greater than $75(\mathrm{MPa})$, i.e. excellent, then the target intermediator of crash strength will be assigned number 10 . Value preferences and target intermediators collectively facilitate the elimination of a weak solution. Further examples of target ranges have been provided in Section 7.

The third step of Set-Based Concurrent Engineering is the development of multiple alternative solutions concurrently. In this step, the designer is expected to develop alternative concepts and provide inputs into the system. To represent the output of multiple solutions, a matrix for communicating alternatives has been employed. In step four, Poka-yoke rules were developed to identify the compatibility of proposed materials and manufacturing processes. 


\begin{tabular}{|l|l|l|}
\hline Targets and graphical visuals & \multicolumn{1}{|c|}{ Target range } & Target intermediator \\
\hline Excellent- $-(-$ & $\begin{array}{l}\text { Defined by designer (See Set-Based Concurrent } \\
\text { Engineering method: Step 2) }\end{array}$ & 10 \\
\hline Acceptable- $\bullet$ & Defined by designer & 7 \\
\hline Marginal- $\boldsymbol{A}$ & Defined by designer & 3 \\
\hline Unacceptable-x & Defined by designer & 0 \\
\hline
\end{tabular}

Table 1: Target range and associated target intermediator

The final step of Set-Based Concurrent Engineering is the reduction of solution space through the elimination of weak solutions. In the developed system, a quantification method has been proposed to eliminate the inferior solution. In this method, each solution is quantified into a single readable number, named the quantification number, as follows; Let $\mathrm{n}$ be the total number of values and $\mathrm{m}$ be the total number of solutions; $\mathrm{P}_{1}, \mathrm{P}_{2}, \ldots, \mathrm{P}_{\mathrm{n}}$ be the customer and company preferences for the values $\mathrm{V}_{1}, \mathrm{~V}_{2}, \ldots, \mathrm{V}_{\mathrm{n}}$ respectively; $\mathrm{T}_{\mathrm{m} 1}, \mathrm{~T}_{\mathrm{m} 2}, \ldots, \mathrm{T}_{\mathrm{mn}}$ be the resultant target intermediator for each value estimate; and $\mathrm{Q}_{1}, \mathrm{Q}_{2}, \ldots, \mathrm{Q}_{\mathrm{m}}$ be the quantification numbers against each solution. The following relation (equation 1) can then be applied to calculate the quantification number.

$\left[\begin{array}{ccccc}T_{11} & T_{12} & \cdot & \cdot & T_{1 n} \\ T_{21} & T_{22} & \cdot & \cdot & T_{2 n} \\ \cdot & \cdot & \cdot & \cdot & \cdot \\ \cdot & \cdot & \cdot & \cdot & \cdot \\ T_{m 1} & T_{m 2} & \cdot & \cdot & T_{m n}\end{array}\right] \times\left[\begin{array}{c}P_{1} \\ P_{2} \\ \cdot \\ \cdot \\ P_{n}\end{array}\right]=\left[\begin{array}{c}Q_{1} \\ Q_{2} \\ \cdot \\ \cdot \\ Q_{m}\end{array}\right]$

The solution with the lowest quantification number will be the weakest solution and will be eliminated prior to the remaining solutions. A case study to illustrate the above explained concept is presented in Section 7.

\subsubsection{Poka-yoke (mistake proofing)}

The objective of Poka-yoke in the developed system is to avoid mistakes in product design and development. For this purpose, rules have been developed to assess geometric features and machine availability at the manufacturing facility, and to make a manufacturability assessment. The geometric features assessment rule is given as follows: 


\section{Geometric features assessment rule}

If

(The sheet thickness is $>0.5 \mathrm{~mm}$ )

AND

(The sheet thickness is $<0.6 \mathrm{~mm}$ )

AND

(Material is Low Carbon Steel)

AND

(Manufacturing process is resistance spot welding)

AND

(Spot spacing is $<=10 \mathrm{~mm}$ )

Then

(Spot space design is within range, Minimum recommended spot space is $10 \mathrm{~mm}$ )

\subsection{System modules}

The system is composed of six modules to generate a systematic cost estimation process for lean product and process development. Each module is developed to support several lean product and process development enablers. These modules are described in detail in the following section.

\subsubsection{Value identification module}

In order to narrow down the solutions, this module provides a list of values for the designer. The designer is required to select the values according to the requirements and is obliged to input the preferences and targets of each value. In total nine values have been identified and integrated into the system, such as product cost and manufacturing time. The list of values has been explained in Section 4.1.2. This list was established from interaction with industry. The system has been structured to generate the results of all nine values. The values can be populated according to requirement.

The value identification module facilitates the Set-Based Concurrent Engineering concept, where the designers communicate explicitly to develop sets of design solutions on the basis of their preferences. These sets help the designers to make the right decisions by eliminating weaker solutions. 


\subsubsection{Manufacturing process / machines selection module}

After the identification of values, designers provide manufacturing process information. This is an important element of the system, because sometime more than one manufacturing process can be suited to a specific part/assembly, e.g. friction welding, electron beam welding, furnace brazing or diffusion brazing. Therefore designers have to select the precise manufacturing process within the acceptable cost boundary. This module is linked to the machine database, which not only helps to identify the manufacturing process(es) capability in the downstream manufacturing facility, but also facilitates in locating the most suitable machine(s).

The manufacturing process / machines selection module supports two lean product and process development enablers, namely Knowledge-based Engineering, and mistake proofing. Rules have been developed to identify the suitable manufacturing processes and designate particular machines available on the manufacturing shop floor. All the machines' information is stored in the machine database (see Table 2).

\begin{tabular}{|l|l|l|l|l|l|l|}
\hline Machine name & $\begin{array}{l}\text { Machine } \\
\text { ID }\end{array}$ & $\begin{array}{l}\text { Machine } \\
\text { Efficiency }(\%)\end{array}$ & $\begin{array}{l}\text { Power of machine } \\
(\mathrm{KWh})\end{array}$ & $\begin{array}{l}\text { Maximum } \\
\text { travel in X axis }\end{array}$ & $\begin{array}{l}\text { Maximum } \\
\text { travel in Y axis }\end{array}$ & $\begin{array}{l}\text { Maximum } \\
\text { travel in Z axis }\end{array}$ \\
\hline Milling Machine & D001 & 90 & 35 & $230 \mathrm{~mm}$ & $75 \mathrm{~mm}$ & $150 \mathrm{~mm}$ \\
\hline Drilling Machine & M001 & 75 & 25 & $200 \mathrm{~mm}$ & $75 \mathrm{~mm}$ & $75 \mathrm{~mm}$ \\
\hline
\end{tabular}

Table 2: An example of the machine database

\subsubsection{Material selection module}

An appropriate material is selected on the basis of part geometry, tolerances, strength, and physical and mechanical properties. The material selection module is coupled with the material database and Cambridge Engineering Selector (CES) software. Table 3 describes an example of a material database. The designer can specify his/her own material, select the material from the system or choose the material from CES software. In case the designer selects the material from the system, information related to material properties, such as material hardness, thermal conductivity, and tensile strength, is provided. The system also allows the designers to select the material from CES or specify their own material details by inserting material information such as density and unit cost. 


\begin{tabular}{|l|l|l|l|l|l|l|l|l|}
\hline $\begin{array}{l}\text { Material } \\
\text { name }\end{array}$ & $\begin{array}{l}\text { Material } \\
\text { ID }\end{array}$ & $\begin{array}{l}\text { Hardness } \\
\mathrm{Bhn}\end{array}$ & $\begin{array}{l}\text { Bulk } \\
\text { modulus } \\
(\mathrm{GPa})\end{array}$ & $\begin{array}{l}\text { Density } \\
\left(\mathrm{Kg} / \mathrm{m}^{3}\right)\end{array}$ & $\begin{array}{l}\text { Thermal } \\
\text { conductivity } \\
(\mathrm{W} / \mathrm{mK})\end{array}$ & $\begin{array}{l}\text { Tensile } \\
\text { strength } \\
(\mathrm{MPa})\end{array}$ & $\begin{array}{l}\text { Maximum } \\
\text { service } \\
\text { temperature } \\
\left({ }^{\circ} \mathrm{C}\right)\end{array}$ & $\begin{array}{l}\text { Minimum } \\
\text { service } \\
\text { temperature } \\
\left({ }^{\circ} \mathrm{C}\right)\end{array}$ \\
\hline $\begin{array}{l}\text { Aluminium } \\
\text { alloys (cast) }\end{array}$ & $\begin{array}{l}\text { MAT- } \\
\text { AL\$ }\end{array}$ & 40 & 63 & $2.67 \times 10^{3}$ & 205 & 76 & 130 & -273 \\
\hline $\begin{array}{l}\text { Steel, } \\
\text { Low carbon }\end{array}$ & $\begin{array}{l}\text { MAT- } \\
\text { SLC\$ } \$\end{array}$ & 100 & 158 & $7.8 \times 10^{3}$ & 50 & 310 & 344 & -68 \\
\hline
\end{tabular}

Table 3: An example of the material database (Cambridge Engineering Selector (CES) software)

Knowledge-based Engineering and Set-Based Concurrent Engineering are facilitated by a material selection module, which supports appropriate material selection and identification of associated material properties from the database. These values present a solution space to take the right decisions; for example, the designer can evaluate alternative materials on the basis of material cost, environmental impact, crash strength and manufacturing time.

\subsubsection{Geometric features specification module}

In this module, the designer specifies the component features information from the CAD file into a geometric features database. This information includes feature name, shape, length and width. An example of a geometric features database of a resistance spot welding process is shown in Table 4.

\begin{tabular}{|l|l|l|l|l|l|l|l|l|l|}
\hline $\begin{array}{l}\text { Feature } \\
\text { ID }\end{array}$ & $\begin{array}{l}\text { Feature } \\
\text { name }\end{array}$ & $\begin{array}{l}\text { Feature } \\
\text { type }\end{array}$ & Dim. Type & $\begin{array}{l}\text { Value } \\
(\mathrm{mm})\end{array}$ & $\begin{array}{l}\text { Edge } \\
\text { distance } \\
(\mathrm{mm})\end{array}$ & $\begin{array}{l}\text { Resistance } \\
\text { spot } \\
\text { spacing } \\
(\mathrm{mm})\end{array}$ & $\begin{array}{l}\text { Seam } \\
\text { length } \\
(\mathrm{mm})\end{array}$ & $\begin{array}{l}\text { Seam } \\
\text { spacing } \\
(\mathrm{mm})\end{array}$ & $\begin{array}{l}\text { No } \\
\text { resistance } \\
\text { spots }\end{array}$ \\
\hline SW1001 & $\begin{array}{l}\text { Resistance } \\
\text { spot Weld }\end{array}$ & Weld & $\begin{array}{l}\text { Length } \\
\text { Width } \\
\text { Thickness }\end{array}$ & $\begin{array}{l}150 \\
25 \\
0.6\end{array}$ & 5 & 5 & 15 & 10 & 06 \\
\hline
\end{tabular}

Table 4: An example of the geometric feature database of a resistance spot welding 
The system has been developed to support designers in the conceptual and detailed design stages. During the conceptual design, since only a small amount of information is available, special measures have therefore been taken to deal with this situation. The designer has to input minimum geometric features information, whereas, the rest of the information is generated on the basis of rules stored in the geometric features database. For example, if the designer selects resistance spot welding (See Table 4); he/she needs to input length, width and thickness. The remaining information, such as edge distance and resistance spot spacing, is generated through the rules stored in the system. However, in the detailed design stage, the designer is required to input complete geometric information.

\subsubsection{Geometric features and manufacturability assessment module}

Once the designer provides geometric features information for a specific subassembly, the system applies assessment rules to uncover the subassembly's manufacturability. In addition, geometric features assessment rules have also been provided to identify that the product has been designed within the recommended range.

This particular module is grounded on mistake proofing and Knowledge-based Engineering enablers. Furthermore, features are assessed using Poka-yoke principles and enable the designer to rectify the design at the early development stage. For example, the minimum recommended sheet thickness for a particular manufacturing process is $3.3 \mathrm{~mm}$; if the designer specifies a thickness less than this recommended number, the system generates an error message and offers a suitable value suggestion. Poka-yoke rules in Section 4.1.3 and the case study in Section 7 demonstrate the above explained concept in detail.

\subsubsection{Manufacturing time and cost estimation module}

In the manufacturing time and cost estimation module, a feature-based cost estimation method has been employed to estimate the manufacturing time and cost for suitable manufacturing processes and materials. Manufacturing cost has been divided into material, labour and equipment running costs. In this module, the designer is allowed to identify high cost and time consumption features. 


\section{SYSTEM SCENARIO}

The developed system supports the designers in both the conceptual and detailed design stages. In the conceptual design stage, it helps decision making, whereas, in the detailed design stage, it facilitates the design assessment to eliminate mistakes in product design. Figure 3 describes the working capability of the system, which is divided into three options.

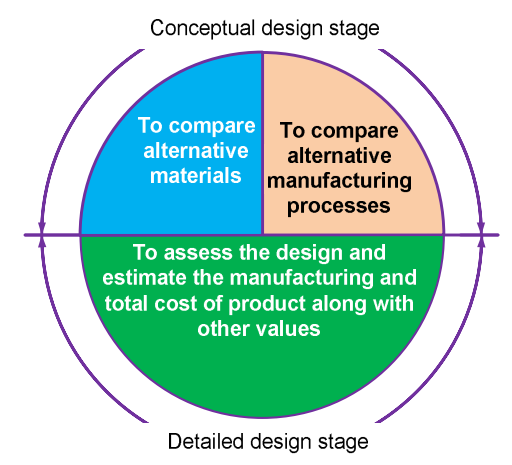

Figure 3: Application of the developed system

Option 1: The system offers decision support to compare alternative materials at the conceptual design stage.

Option 2: The system provides decision support to compare alternative manufacturing processes at the conceptual design stage.

Option 3: The system helps to assess the design mistakes and estimates the manufacturing and total cost of product along with other values in the detailed design stage.

The scenario of the cost estimation process for the conceptual and detailed design stages is illustrated in Figure 4. For the conceptual design, the estimation process follows the five steps of Set-based Concurrent Engineering which have been explained in Section 4.1.2. In step 1 (See Figure 4), the system prompts the designer to choose the values from a comprehensive option list. The designer selects the values and specifies his/her preferences. In the $2^{\text {nd }}$ step, the designer is required to input the targets of each value. Examples of values, values preferences and their targets have been provided in Table 5. In step 3, he/she constructs a conceptual part model, and specifies alternative manufacturing processes, alternative materials and complete CAD model information. Once the information has been provided, the system examines each feature for its 
compatibility by applying the Poka-yoke (mistake proofing) rules stored in the knowledge database in step 4. These Poka-yoke rules help to identify the machines' availability at the manufacturing facility, and make a manufacturability assessment. If the feature does not accomplish the Poka-yoke criteria, then the system prompts the designer to modify the part model. Further explanation of Poka-yoke is available Section 4.1.3. Once each feature is found to be suitable for manufacturing, the system generates an estimate of manufacturing time, cost and all other values required by the designer. Steps 3 and 4 (Figure 4) are repeated until manufacturability, manufacturing cost and other required values of the entire product are estimated. After that the system displays the matrix for communicating alternatives to express the output of all values. Finally, in step 5, a solution narrowing down method (quantification method) has been put in place to eliminate the weak solution. Section 4.1.2 presents a detailed explanation of the quantification method.

Once the strong solution is selected in the conceptual design stage, it is further developed by the designer in the detailed design stage. Final details, CAD/CAM model, FEA (finite element analysis) tests, and assembly and product structure are finalised in the detailed design stage. The developed system helps the designer to identify design mistakes and give detailed estimates in this stage. It is important to note that the system generates the estimates for cost along with the other eight values explained in Section 4.1.2. The estimation process is composed of four steps in total, out of which steps 1 and 2 are similar to the conceptual design stage. In step 1 (Figure 4), required values and their preferences are provided by the designer, whereas in step 2, each value's target is supplied. In step 3, the designer specifies the material, manufacturing process and CAD model information. After providing detailed information, the system applies Pokayoke principles to detect any design mistakes in step 4 (Figure 4). An example of Poka-yoke assessment rules has been provided in Section 4.1.3. Once the product is identified as mistake proof, manufacturing time, cost and all required values are estimated. 
Cost modelling for lean product and process development

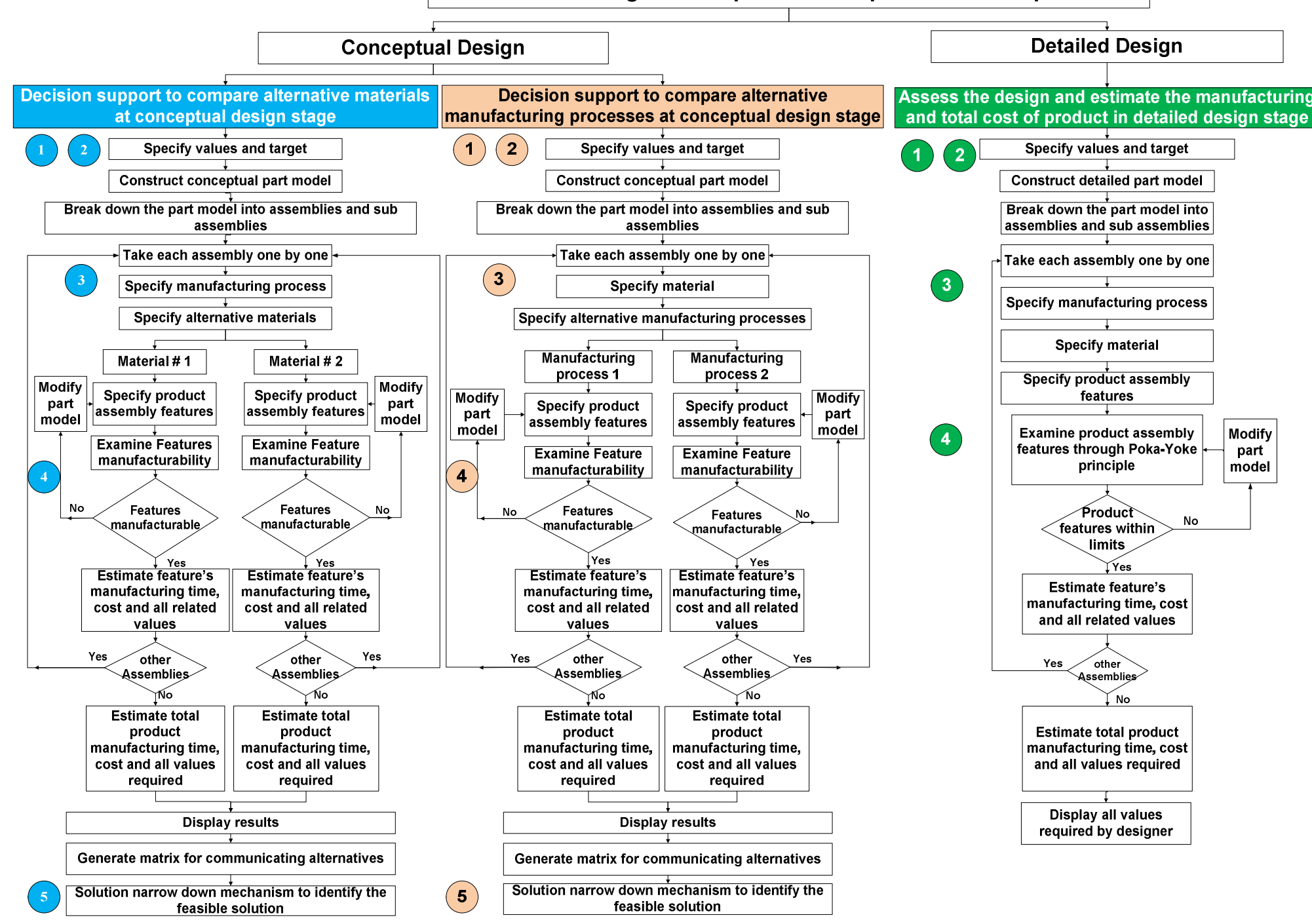

Figure 4: System scenario 


\section{SYSTEM IMPLEMENTATION AND BENEFITS}

This system has been designed to provide users with an integration environment for the cost estimation of multiple applications. It is an end-to-end and service-oriented application based on .NET enterprise application server technologies. The system offers full interoperability with Java enterprise and Oracle servers. This application is developed in C\# 3.0 within the .NET Framework and Microsoft SQL Server 2008. The user interface design concentrates on building a client-side application using Windows Forms to meet the industrial user's requirements. The MS SQL server database is employed to design and build up rules and knowledge.

The system provides a number of benefits, as it enables the designers to incorporate lean thinking into the cost estimation. It also allows for the consideration of downstream manufacturable process information at an early upstream stage of the design and as a result the designer performs the process concurrently and makes decisions quickly. Moreover, the system helps to avoid mistakes during the product features design, material and manufacturing process selection, and process parameters generation; hence it guides towards a mistake proof product development. The main feature of the system in addition to manufacturing cost estimation is the Set-Based Concurrent Engineering support. The system provides a number of design values for alternative design concepts to identify the feasible design region.

\section{SYSTEM VALIDATION}

The system has been validated through a case study with one of the industrial partners involved in the LeanPPD project. The core business of this industrial partner is the development and manufacture of steel structures and entire seats for vehicles (Figure 5). The company has its development and manufacturing facilities in Europe, India and China. The collaborative research with the industrial partner showed that they currently had an unformalised cost estimation method; hence they greatly relied on experts' judgement. The majority of the decisions made were based on company values without any customer involvement which resulted in customer dissatisfaction. Therefore, it was the company's desire to incorporate customer values into the system in order to enhance decision making. The company was researching for new materials suitable for seat manufacture in order to address some of the challenges they were encountering. The company was also facing challenges due to incorrect product design. Resistance spot 
welding is a key process to join seat assemblies; however, the designers had assigned the wrong number of spots on $50 \%$ to $80 \%$ of the components. The wrong design had caused a huge impact on product cost, production volume and required weight. Therefore, the company was keen to apply Poka-yoke principles to eliminate mistakes during the early design stage. A sample of four assemblies was selected to validate the system.

First of all, the company product development process was laid down as shown in Figure 6. In the concept development stage the company develops a rough CAD model followed by an FEA (finite element analysis) with a crash test simulation. Once the crash test is approved, the company develops the initial quotation to win the project, whereas, in the detailed design stage, a detailed CAD model, CAE stamping modelling, fine FEA, and tolerance checks are performed before releasing the CAD drawing. In the conceptual design stage, the company was interested to compare alternative designs with aluminium alloy and low carbon steel in order to identify the best material. In addition, the company was looking at the quotation development. In the detailed design stage, the company would like to be able to identify design mistakes before estimating the manufacturing and total cost of product along with other values.

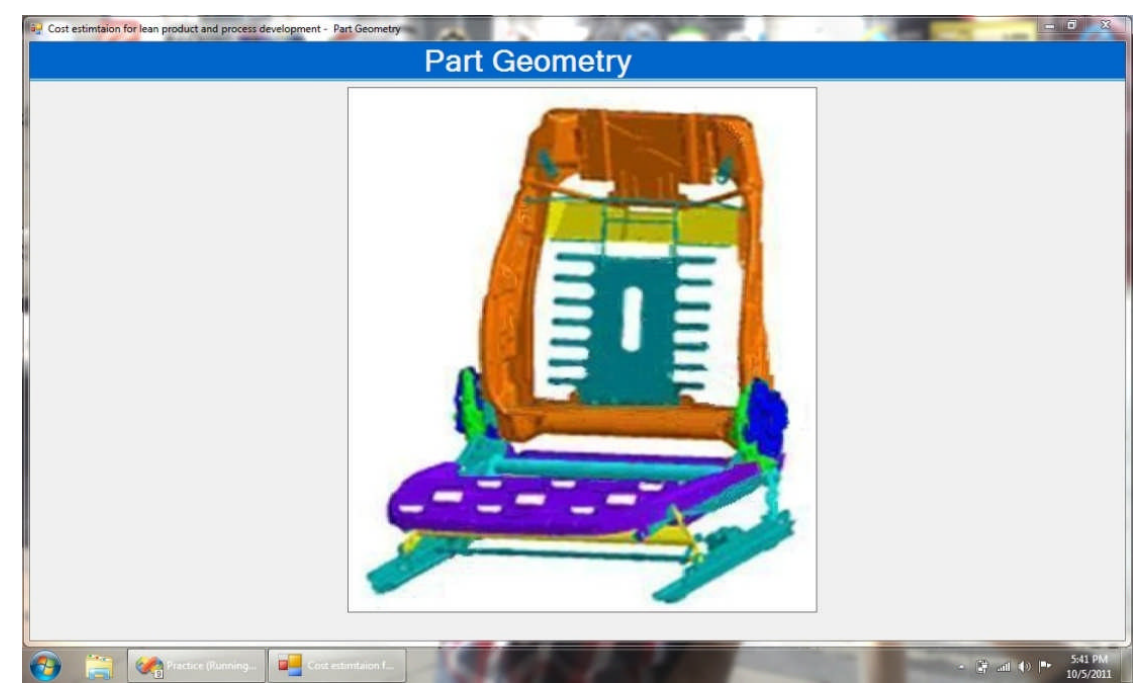

Figure 5: Structure of a seat 


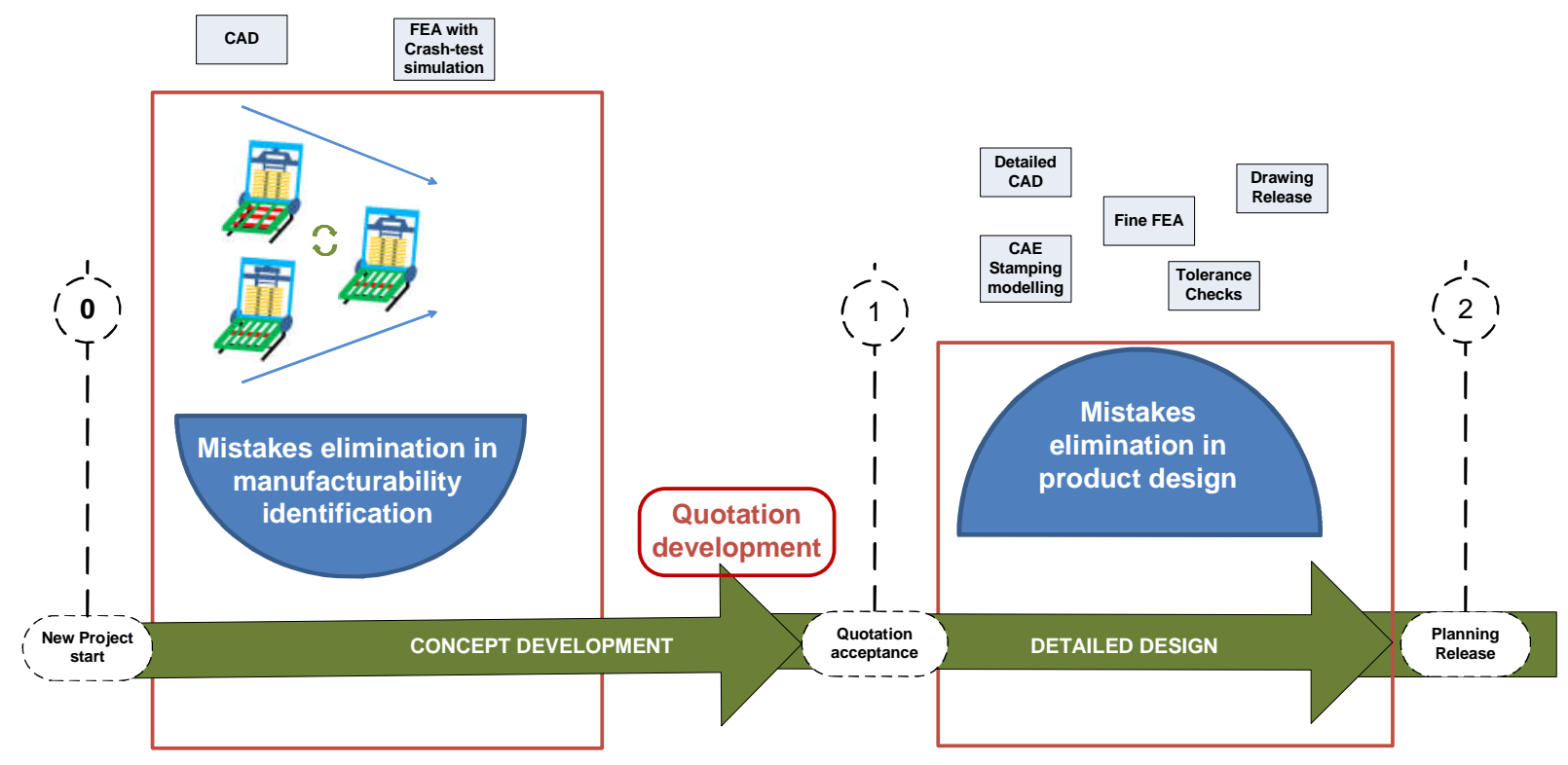

Figure 6: Product development process in the case study company

To validate the system for the conceptual design stage, the first step was the identification of values, as explained in system scenario (Section 5). The company has identified five core values: product weight, tensile strength, product cost, maximum service temperature, and production volume. The values preferences and their targets are presented in Table 5. After that the required product information was input into the system which includes: alternative materials, manufacturing process (resistance spot welding) and CAD model geometric features information. The system applied the manufacturability assessment rules to find the materials' capability and generates estimates for manufacturing time and cost. Figure 7 demonstrates the snapshot of the developed system. The time and cost analysis of resistance spot welding has been explained in the next section.

\begin{tabular}{|c|c|c|c|c|c|c|c|}
\hline \multirow[t]{2}{*}{ Value } & \multirow{2}{*}{$\begin{array}{c}\text { Company } \\
\text { value }\end{array}$} & \multirow{2}{*}{$\begin{array}{l}\text { Customer } \\
\text { Value }\end{array}$} & \multirow[t]{2}{*}{ Preferences } & \multicolumn{4}{|c|}{ Targets } \\
\hline & & & & $\begin{array}{c}\text { Excellent } \\
\odot ;\end{array}$ & Acceptable & Marginal & $\begin{array}{c}\text { Unacceptable } \\
x\end{array}$ \\
\hline $\begin{array}{l}\text { Product weight } \\
(\mathrm{Kg})\end{array}$ & Yes & Yes & 10 & $\begin{array}{c}\text { Less than } \\
3.0 \mathrm{Kg}\end{array}$ & $\begin{array}{l}3.0 \mathrm{Kg} \text { to } \\
4.5 \mathrm{Kg}\end{array}$ & $\begin{array}{c}4.5 \mathrm{Kg} \text { to } \\
6.0 \mathrm{Kg}\end{array}$ & $\begin{array}{c}\text { Greater than } \\
6.0 \mathrm{Kg}\end{array}$ \\
\hline $\begin{array}{l}\text { Tensile strength } \\
\text { (MPa) }\end{array}$ & Yes & Yes & 9 & $\begin{array}{l}\text { Greater } \\
\text { than } \\
100 \mathrm{MPa}\end{array}$ & $\begin{array}{l}75 \mathrm{MPa} \text { to } \\
100 \mathrm{MPa}\end{array}$ & $\begin{array}{l}50 \mathrm{MPa} \text { to } \\
75 \mathrm{MPa}\end{array}$ & $\begin{array}{l}\text { Less than } \\
50 \mathrm{MPa}\end{array}$ \\
\hline Product cost $(\mathfrak{f})$ & Yes & Yes & 7 & $\begin{array}{l}\text { Less than } \\
£ 59.0\end{array}$ & $£ 59$ to $£ 61$ & $\begin{array}{l}£ 61 \text { to } \\
£ 63\end{array}$ & $\begin{array}{c}\text { Greater than } \\
£ 63\end{array}$ \\
\hline
\end{tabular}




\begin{tabular}{|l|c|c|c|c|c|c|c|}
\hline $\begin{array}{l}\text { Maximum } \\
\text { service } \\
\text { temperature }\left({ }^{\circ} \mathrm{C}\right)\end{array}$ & Yes & Yes & 7 & $\begin{array}{c}\text { Greater } \\
\text { than } \\
150^{\circ} \mathrm{C}\end{array}$ & $\begin{array}{c}100^{\circ} \mathrm{C} \text { to } \\
150^{\circ} \mathrm{C}\end{array}$ & $\begin{array}{c}75^{\circ} \mathrm{C} \text { to } \\
100^{\circ} \mathrm{C}\end{array}$ & $\begin{array}{c}\text { Less than } \\
75^{\circ} \mathrm{C}\end{array}$ \\
\hline $\begin{array}{l}\text { Production } \\
\text { volume (Units } \\
\text { per day) }\end{array}$ & Yes & No & 7 & $\begin{array}{c}\text { Greater } \\
\text { than } 400 \\
\text { units per } \\
\text { day }\end{array}$ & $\begin{array}{c}350 \text { to } 400 \\
\text { units per } \\
\text { day }\end{array}$ & $\begin{array}{c}300 \text { to } \\
350 \text { units } \\
\text { per day }\end{array}$ & $\begin{array}{c}\text { Less than } \\
300 \text { units per } \\
\text { day }\end{array}$ \\
\hline
\end{tabular}

Table 5: Values, value preferences and targets

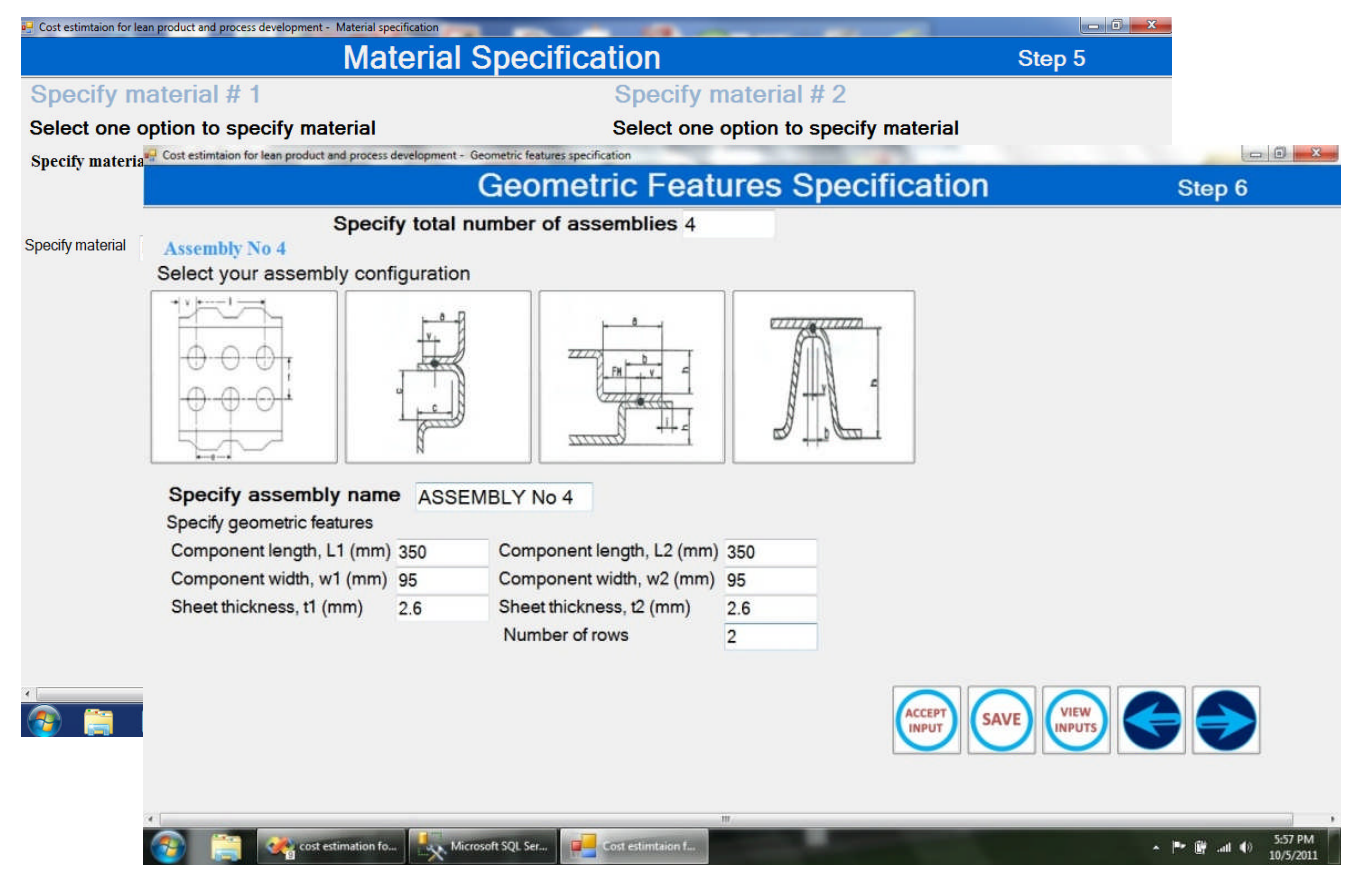

Figure 7: Snapshot of the developed system

\subsection{Time analysis of resistance spot welding}

Resistance spot welding manufacturing time includes squeeze time, weld time and hold time, along with part setup and part removal time (Aslanlar, 2006; Xu and Zhai, 2008); where squeeze time is the time period between the preliminary electrode force application on the work and the initial current application, weld time is the time when the current actually passes through the electrode and melts the parts to join them together, and hold time is the time required to solidify and chill the part. In order to obtain the desired weld, the weld current should be prolonged until the electrode obtains the desired level. Figures $8 \mathrm{a}$ and $8 \mathrm{~b}$ show the times for one weld and ' $n$ ' number of welds respectively. Similarly, equations (2-3) estimate the welding time for one and 'n' number of welds respectively. 


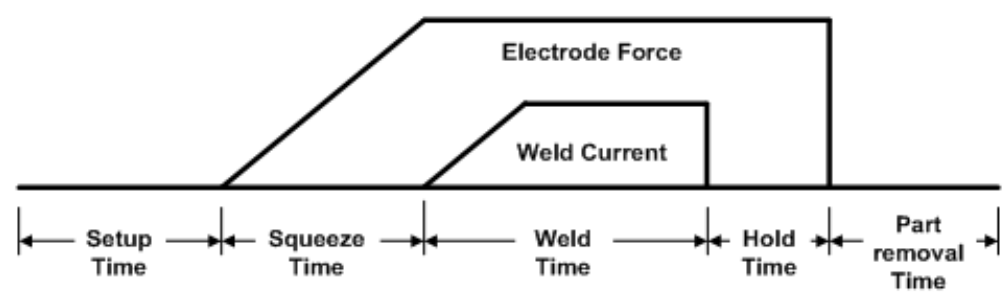

Fig 8a: Resistance spot welding time for one weld (Adapted from Aslanlar, 2006 and Xu and Zhai, 2008)

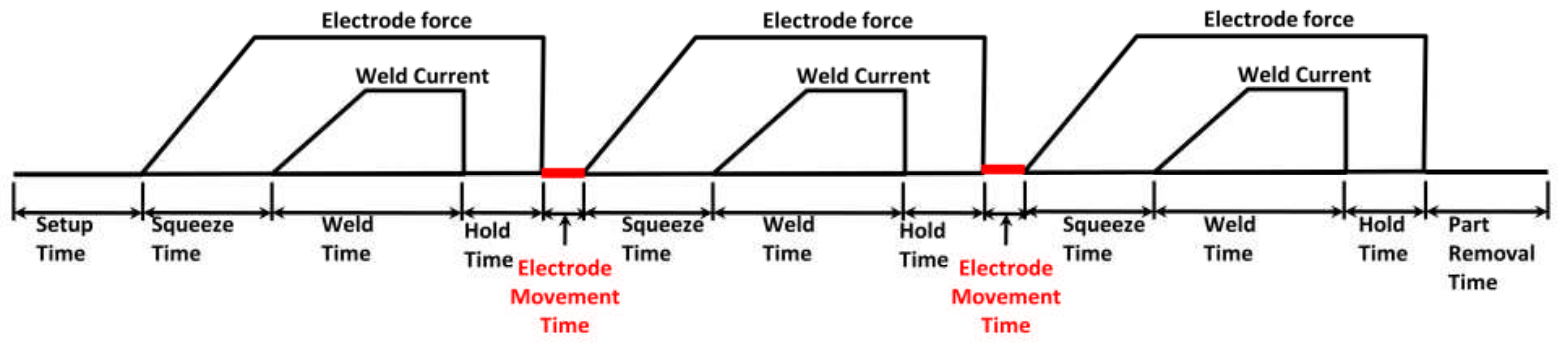

Fig 8b: Resistance spot welding time for " $\mathrm{n}$ " welds, $\mathrm{n}=3$

$T_{t}=T_{s u}+T_{s q}+T_{\text {weld }}+T_{\text {hold }}+T_{p_{-} \text {rem }}$

$T_{t^{\prime}}=T_{\text {su }}+n\left(T_{\text {sq }}+T_{\text {weld }}+T_{\text {hold }}\right)+(n-1)\left(T_{\text {elec_m }}\right)+T_{p_{-} \text {rem }}$

Where

$T_{t}=$ RSW time for one weld

$T_{t}$ ' $=$ RSW time for ' $\mathrm{n}$ ' numbers of weld

$T_{s u}=$ Set up time

$T_{s q}=$ Squeeze time

$T_{\text {weld }}=$ Weld time

$T_{\text {hold }}=$ Part holding time

$T_{\text {elec_ } m}=$ Electrode movement time, and

$T_{p_{-} \text {rem }}=$ Part removal time

\subsection{Welding cost estimation}

Predicting the welding cost mainly depends on the major cost drivers associated with the manufacturing process. A comprehensive literature review was conducted to identify these cost drivers. Special attention was made to categorise drivers related to welding processes; Table 6 presents these drivers. Material cost, labour cost, and equipment running cost are major drivers in welding cost estimation. For resistance spot welding, the equipment running process was further studied in detail and the following cost drivers were identified, namely power 
consumption, part holding and electrode movement costs. Once the cost drivers were fixed, a cost was designated to each driver.

\section{Material cost:}

The material cost $\mathrm{C}_{\mathrm{mt}}$ for resistance spot welding may be estimated as follows (Shehab and Abdalla, 2001).

$\mathrm{C}_{\mathrm{mt}}=\mathrm{V} \rho \mathrm{C}_{\mathrm{m}}$

Where $\mathrm{V}$ is the component volume in $\mathrm{m}^{3}, \rho$ is the material density in $\mathrm{Kg} / \mathrm{m}^{3}, \mathrm{C}_{\mathrm{m}}$ is the material unit price in $\mathfrak{f} / \mathrm{Kg}$.

\begin{tabular}{|c|c|c|c|c|c|c|}
\hline $\begin{array}{l}\text { Researcher } \\
\text { Cost } \\
\text { drivers }\end{array}$ & $\begin{array}{l}\text { (Ye et al., } \\
2009)\end{array}$ & $\begin{array}{l}\text { (Chayoukhi et al., } \\
\text { 2009) }\end{array}$ & $\begin{array}{l}\text { (Ravisankar et al., } \\
\text { 2006) }\end{array}$ & $\begin{array}{l}\text { (Brinke, } \\
\text { 2002) }\end{array}$ & $\begin{array}{l}\text { (Feder, 1993) } \\
\text { as explained } \\
\text { by (Schreve, } \\
\text { 1997) }\end{array}$ & $\begin{array}{l}\text { (Benyounis et } \\
\text { al., 2008) }\end{array}$ \\
\hline Material & $\begin{array}{l}\text { Material } \\
\text { cost }\end{array}$ & Material cost & & $\begin{array}{l}\text { Part, } \\
\text { geometry } \\
\text { and material }\end{array}$ & $\begin{array}{l}\text { Part, volume } \\
\text { and density }\end{array}$ & \\
\hline Labour & Labour cost & Labour cost & Labour cost & & & \\
\hline \multirow[t]{4}{*}{$\begin{array}{l}\text { Equipment } \\
\text { running cost }\end{array}$} & \multirow[t]{4}{*}{$\begin{array}{l}\text { Equipment } \\
\text { cost }\end{array}$} & $\begin{array}{l}\text { Electrode } \\
\text { consumption cost }\end{array}$ & Electrode cost & \multirow[t]{4}{*}{$\begin{array}{l}\text { Equipment } \\
\text { cost }\end{array}$} & \multirow[t]{4}{*}{$\begin{array}{l}\text { Equipment } \\
\text { cost }\end{array}$} & \multirow[t]{4}{*}{$\begin{array}{l}\text { Equipment } \\
\text { cost }\end{array}$} \\
\hline & & $\begin{array}{ll}\text { Gas } & \text { consumption } \\
\text { cost } & \end{array}$ & Shielding gas & & & \\
\hline & & $\begin{array}{l}\text { Electric energy / } \\
\text { power consumption } \\
\text { cost }\end{array}$ & Power cost & & & \\
\hline & & $\begin{array}{l}\text { Welding post } \\
\text { consumption cost }\end{array}$ & Filler metal cost & & & \\
\hline
\end{tabular}

Table 6: Cost drivers for manufacturing process (welding process)

\section{Labour cost}

The labour cost is the function of time required to complete the process multiplied by the labour unit cost. It can be calculated through the following expression (Ye et al., 2009).

$\mathrm{C}_{\mathrm{lb}}=\mathrm{C}_{\mathrm{l}} \times \sum_{\mathrm{i}=1}^{\mathrm{N}} \mathrm{Lb}_{\mathrm{i}} \times \mathrm{T}_{\mathrm{i}}$ 
Where $C_{l b}$ represents the labour cost in $£, C_{1}$ is the labour unit cost in $£ / h r, L b_{i}$ is the number of labours in ith operation and $\mathrm{T}_{\mathrm{i}}$ stands for the process time in ith operation.

\section{Power consumption cost}

In resistance spot welding, energy is consumed to weld the parts. Energy consumption depends upon weld time, welding power, machine efficiency and number of resistance spots. The following expression represents the power consumption cost in resistance spot welding (Klansek and Kravanja, 2006).

$$
\mathrm{C}_{\text {pow }}=\mathrm{C}_{\mathrm{p}} \times \frac{\mathrm{I}_{\text {weld }} \times \mathrm{V}_{\text {weld }} \times \mathrm{T}_{\text {weld }}}{\eta_{\text {weld }} \times 3600} \times \mathrm{n}
$$

Where $\mathrm{C}_{\text {pow }}$ denotes the power consumption cost of the electrode in $£, C_{p}$ represents the unit energy price in $£ / \mathrm{KWh}, \mathrm{I}_{\text {weld }}$ is the weld current in $\mathrm{KA}, \mathrm{V}_{\text {weld }}$ is the welding voltage in volts, $\eta_{\text {weld }}$ is the welding machine efficiency, $\mathrm{T}_{\text {weld }}$ is the weld time and $\mathrm{n}$ is the number of spots.

\section{Part holding cost}

In resistance spot welding, energy is consumed to hold the parts. It depends upon the holding force requirement, total holding time, holding equipment efficiency and number of spots. Part holding cost is estimated using the relation below.

$$
\mathrm{C}_{\text {hold }}=\mathrm{C}_{\mathrm{p}} \times \frac{\mathrm{P}_{\text {equip }}}{\eta_{\mathrm{w}} \times 3600} \times\left(\mathrm{T}_{\mathrm{sq}}+\mathrm{T}_{\text {weld }}+\mathrm{T}_{\text {hold }}\right) \times \mathrm{n}
$$

Where $C_{\text {hold }}$ expresses the part holding cost in $£, C_{p}$ is the unit energy price in $£ / K W h, P_{\text {equip }}$ is the power of the holding equipment in $\mathrm{KW}$, $\eta_{\text {hold }}$ is the holding equipment efficiency, $\mathrm{T}_{\mathrm{sq}}$ is the squeeze time, $\mathrm{T}_{\text {weld }}$ is the weld time, $\mathrm{T}_{\text {hold }}$ is the hold time and $\mathrm{n}$ represents the total number of spots.

\section{Electrode movement cost}

Energy in resistance spot welding is also consumed during the electrode movement time and depends upon electrode/robot speed, distance covered by robot, i.e. total distance between spots, and equipment efficiency. The following equations (8-9) can be applied to estimate the electrode movement cost. 
$\mathrm{C}_{\text {elec } \_\mathrm{m}}=\mathrm{C}_{\mathrm{p}} \times \frac{\mathrm{P}_{\mathrm{rob}} \times \mathrm{d}_{\Sigma}}{\eta_{\mathrm{rob}} \times 3600 \times \mathrm{v}} \times \mathrm{n}$

And $\quad \mathrm{d}_{\Sigma}=\sum_{\mathrm{i}}^{\mathrm{n}} \mathrm{d}_{\mathrm{i}}$

Where $C_{\text {elec_m }}$ denotes the electrode movement cost in $£, C_{p}$ is the unit energy price in $£ / K W h$, $P_{\text {rob }}$ is the power of the robot or electrode in $\mathrm{KW}, \eta_{\text {rob }}$ is the robot efficiency, $d_{\Sigma}$ is total distance covered by the robot, $d_{i}$ is the distance between each spot and $v$ is the velocity of the robot.

\section{Setup and part removal cost}

Setup and part removal costs and times are crucial in the mass production environment. These times include the times required to adjust the tooling and programme the robot. The times for different jigs and fixtures can be calculated and placed in the database to obtain a more accurate cost estimation.

Once the time and cost of all assemblies were estimated, the system calculated all values requested. The summary of results is expressed in Figure 9. The matrix for communicating alternatives (Table 7) was also developed to evaluate low carbon steel and aluminium alloy.

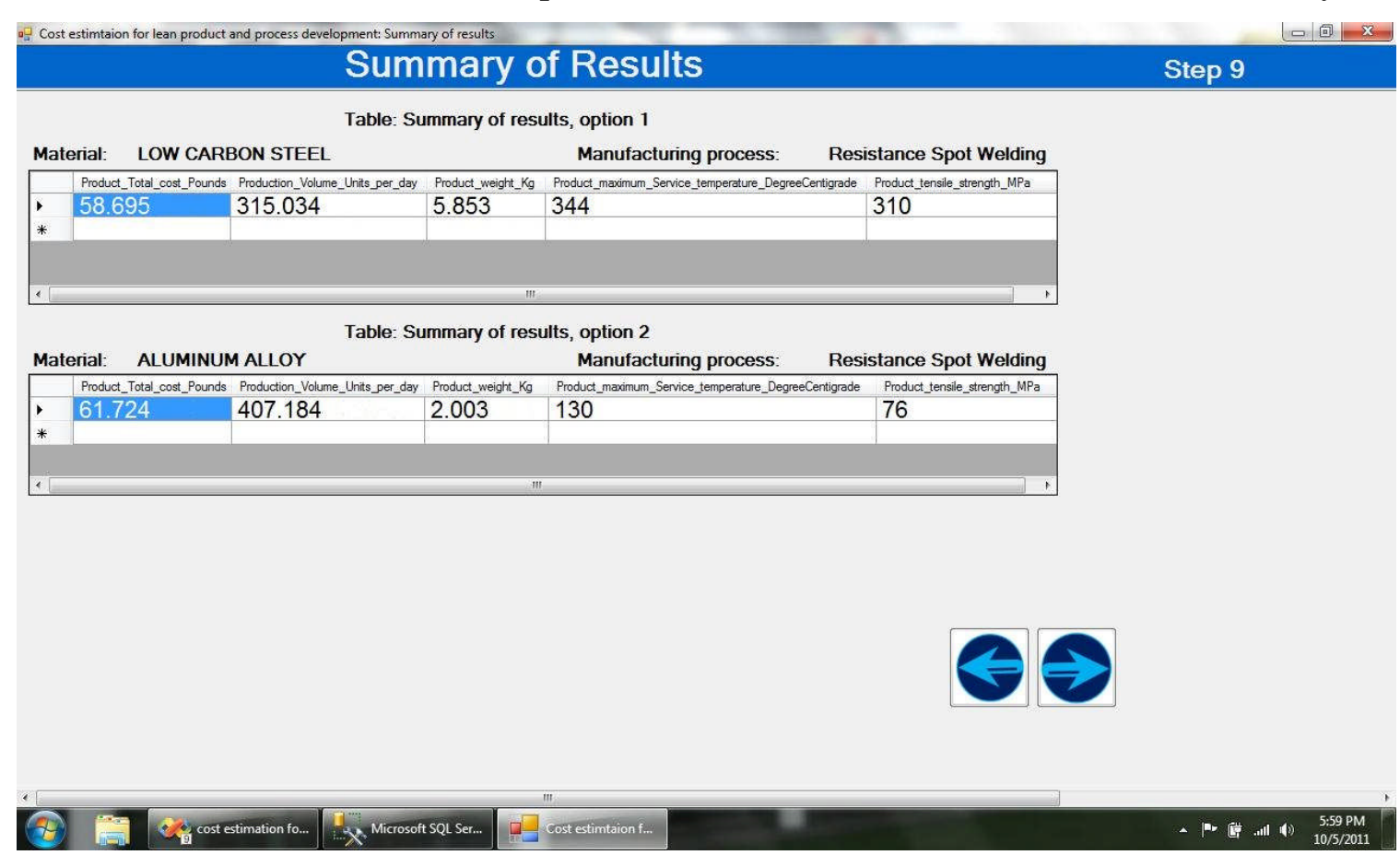

Figure 9: Summary of results 


\begin{tabular}{|c|c|c|}
\hline Material & Low carbon steel & Aluminium alloy \\
\hline Product weight $(\mathrm{Kg})$ & $\Delta$ & 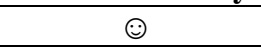 \\
\hline Tensile strength (MPa) & (;) & $\bullet$ \\
\hline Product cost (£) & (:) & $\Delta$ \\
\hline Maximum service temperature $\left({ }^{\circ} \mathrm{C}\right)$ & (): & $\bullet$ \\
\hline Production volume (Units per day) & $\Delta$ & (): \\
\hline
\end{tabular}

Table 7: Matrix for communicating alternatives

Finally relation (1) was applied to generate the quantification number of each design solution (See equation 10). It can be seen from the result that the low carbon steel has the lowest quantification number, therefore it was eliminated. Since the aluminium alloy is the only remaining solution, it can therefore be selected as the best solution and the estimated cost can be used for the quotation.

$\left[\begin{array}{ccccc}3 & 10 & 10 & 10 & 3 \\ 10 & 7 & 3 & 7 & 10\end{array}\right] \times\left[\begin{array}{c}10 \\ 9 \\ 7 \\ 7 \\ 7\end{array}\right]=\left[\begin{array}{l}281 \\ 303\end{array}\right]=\left[\begin{array}{l}\text { Low carbon steel } \\ \text { Aluminium alloy }\end{array}\right]$

To validate the system for the detailed design stage, it was explained earlier that the company focuses on the application of the Poka-yoke (mistake proofing) principle in their design facility. The system scenario explained in Section 5 was followed step by step, i.e. values, value preferences, value targets, CAD model, material and manufacturing process information were all provided in sequence. Since the manufacturing process was resistance spot welding, the design mistakes related to sheets overlap, edge distance, spot spacing and total number of spots were therefore identified. The example of Poka-yoke related to overlap has been provided in Figure 10. Once all the mistakes were captured, manufacturing time, cost and all required values were estimated accordingly. 


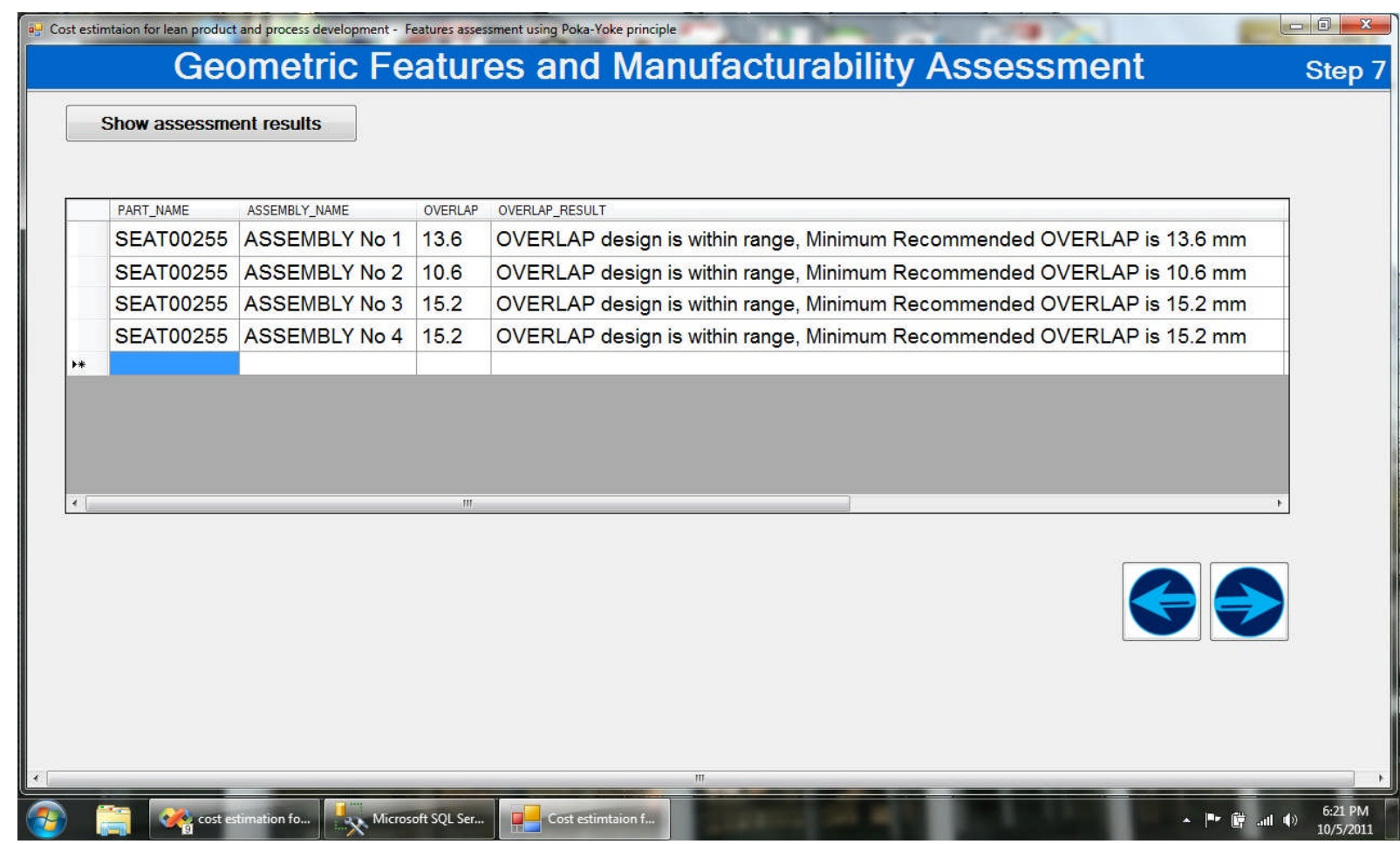

Figure 10: Application of Poka-yoke

After the adoption of the developed system, the company has gained a number of tangible benefits (Table 8). These benefits truly represent the advantages of cost estimation for lean product and process development.

\begin{tabular}{|l|l|l|}
\hline & Before & After \\
\hline Design mistake & $50 \%-80 \%$ & $5-10 \%$ \\
\hline Cost estimation time & 25 days & $12-15$ days \\
\hline Internal meetings to finalise design & $4-6$ & $2-3$ \\
\hline Quotation response time & 3 months & 1 month \\
\hline
\end{tabular}

Table 8: Tangible benefits obtained after the adoption of the developed system

\section{CONCLUSIONS}

A novel cost estimation system for lean product and process development has been presented in this research paper. The system is developed in C\# 3.0 within .NET Framework and Microsoft SQL Server 2008. The system is composed of a user interface, three lean enablers, namely SetBased Concurrent Engineering, Knowledge-based Engineering, and mistake proofing (Pokayoke), six modules, and a knowledge database. 
A user friendly environment assists designers to easily input the data into the system and analyse the results. The narrow down mechanism proposed in the Set-Based Concurrent Engineering process helps the designers to narrow down the solutions space by eliminating the weak solution. Poka-yoke principle-based rules have been implemented to eliminate mistakes in both the conceptual and detailed design stages. In the conceptual design stage, the system eliminates mistakes in manufacturability, materials and manufacturing process selection, whereas, in the detailed design stage, product design mistakes are also eliminated.

The developed system has the capability to: (i) provide estimates related to product cost and associated values concurrently; (ii) facilitate decision making by narrowing down the alternative solution gradually; (iii) eliminate mistakes at the design stage, and (iv) incorporate customer voice in the decision making. The system has been validated through an industrial case study. The results obtained through the case study have shown an improvement in terms of product cost and associated values estimation, decision making, mistakes elimination, and quotation response time. The work is a part of on-going lean product and process development (LeanPPD) project, which aims to develop a new cost model that enables designers to make the right decisions and avoid mistakes at the product development design stage. There is a need to incorporate tools such as trade-off curves into the current system capability which could then be used to make sound judgements based on mathematical justification through graphic visuals.

\section{ACKNOWLEDGEMENTS}

The authors would like to thank the University of Engineering and Technology Taxila (Pakistan) and Cranfield University for funding this $\mathrm{PhD}$ research. They wish to record their appreciation and gratitude to the LeanPPD EU-FP7 project for the scientific support given to this research.

\section{REFERENCES}

Al-Ashaab, A., Shehab, E., Alam, R., Sopelana, A., Sorli, M., Flores, M., Taisch, M., Stokic, D. and James-Moore, M. (2010), "The Conceptual LeanPPD Model", Proceedings of the 17th ISPE International Conference on Concurrent Engineering, 6-10 September, Warsaw University of Technology, Cracow, Poland. 
Aslanlar, S. (2006), "The effect of nucleus size on mechanical properties in electrical resistance spot welding of sheets used in automotive industry", Materials \& Design, vol. 27, no. 2, pp. $125-131$

Benyounis, K., Olabi, A. and Hashmi, M. (2008), "Multi-response optimization of $\mathrm{CO}_{2}$ laserwelding process of austenitic stainless steel", Optics \& Laser Technology, vol. 40, no. 1, pp. 76-87.

Bouaziz, Z., Younes, J. B. and Zghal, A. (2006), "Cost estimation system of dies manufacturing based on the complex machining features", The International Journal of Advanced Manufacturing Technology, vol. 28, no. 3, pp. 262-271.

Brinke, E. (2002), Costing support and cost control in manufacturing. A cost estimation tool applied in the sheet metal domain. PhD Thesis, Vakgroep Ontwerpen, University of Twente.

Chan, D. S. K. (2003), "Expert system for product manufacturability and cost evaluation", Materials and Manufacturing Processes, vol. 18, no. 2, pp. 313-322.

Chan, D. S. K. and Lewis, W. P. (2000), "The integration of manufacturing and cost information into the engineering design process", International Journal of Production Research, vol. 38, no. 17 , pp. $4413-4427$.

Chayoukhi, S., Bouaziz, Z. and Zghal, A. (2009), "COSTWELD: A cost estimation system of welding based on the feature model", Advances in Production Engineering and Management, vol. 4, no. 4, pp. 263-274.

Cicconi, P., Germani, M. and Mandolini, M. (2010), "How to Support Mechanical Product Cost Estimation in the Embodiment Design Phase", New World Situation: New Directions in Concurrent Engineering, Springer-Verlag London Limited, pp. 419-430.

Curran, R., Verhagen, W. J. C., van der Laan, T. H. and van Tooren, M. (2009), "KBE and manufacturing constraints management", Global Perspective for Competitive Enterprise, Economy and Ecology, pp. 783-791.

Djassemi, M. (2008), "A computer-based economic analysis for manufacturing process selection", Proceedings of the 2008 IAJC-IJME International Conference, Nov. 2008, Nashville, Tennessee, US.

Er, A. and Dias, R. (2000), "A rule-based expert system approach to process selection for cast components", Knowledge-Based Systems, vol. 13, no. 4, pp. 225-234. 
Esawi, A. M. K. and Ashby, M. F. (2003), "Cost estimates to guide pre-selection of processes", Materials \& Design, vol. 24, no. 8, pp. 605-616.

Feder, D. K. (1993), "Cost Implications in the design of welded steels structures", Welding in the World, vol. 31, no. 4.

Feng, S. and Zhang, Y. (1999), "Conceptual process planning - a definition and functional decomposition", Manufacturing Science and Engineering, Proceedings of the 1999 International Mechanical Engineering Congress and Exposition, Vol. 10, Citeseer, pp. 91106.

Jamaludin, R. (2008), "A Product-Based Non-Conformance Classification", Proceedings of the 9th Asia Pasific Industrial Engineering \& Management Systems Conference (APIEMS 2008), 3rd - 5th Dec, Nusa Dua, Bali, Indonesia, pp. 2846-2854.

Kennedy, M., Harmon, K. and Minnock, E. (2008), Ready, set, dominate: Implement Toyota's set-based learning for developing products, Oakley Press.

Khan, M., Al-Ashaab, A., Doultsinou, A., Shehab, E., Ewers, P. and Sulowski, R. (2011a), "SetBased Concurrent Engineering process within the LeanPPD environment", Improving Complex Systems Today, advanced Concurrent Engineering, doi: 10.1007/ 978-0-85729799-0_51, pp. 433-440.

Khan, M., Al-Ashaab, A., Shehab, E., Haque, B., Ewers, P., Sorli, M. and Sopelana, A. (2011b), "Towards Lean Product and Process Development", Accepted for publication in the Lean PD special issue of Internation Journal of Computer Integrated Manufacturing.

Klansek, U. and Kravanja, S. (2006), "Cost estimation, optimization and competitiveness of different composite floor systems - Part 1: Self-manufacturing cost estimation of composite and steel structures", Journal of Constructional Steel Research, vol. 62, no. 5, pp. 434-448.

Kremer, R. and Fabrizio, T. (2005), The Lean Primer-Solutions for the Job Shop, MCS Media, Inc., Chelsea, MI 48118, US.

Mascitelli, R. (2004), The Lean Design Guidebook, Technology Perspectives, Northridge, CA.

Masmoudi, F., Bouaziz, Z. and Hachicha, W. (2007), "Computer-aided cost estimation of weld operations", The International Journal of Advanced Manufacturing Technology, vol. 33, no. 3, pp. 298-307. 
Mauchand, M., Siadat, A., Bernard, A. and Perry, N. (2008), "Proposal for tool-based method of product cost estimation during conceptual design", Journal of Engineering Design, vol. 19, no. 2 , pp. $159-172$.

Mital, A., Desai, A., Subramanian, A. and Mital, A. (2008), Product development: a structured approach to consumer product development, design, and manufacture, ButterworthHeinemann, Oxford, UK.

Morgan, J. M. and Liker, J. K. (2006), The Toyota product development system: integrating people, process, and technology, New York ed, Productivity Press.

Niazi, A., Dai, J. S., Balabani, S. and Seneviratne, L. (2006), "Product cost estimation: technique classification and methodology review", Journal of Manufacturing Science and Engineering, vol. 128, no. 2, pp. 563-575.

Ou-Yang, C. and Lin, T. S. (1997), "Developing an integrated framework for feature-based early manufacturing cost estimation", The International Journal of Advanced Manufacturing Technology, vol. 13, no. 9, pp. 618-629.

Quintana, G. and Ciurana, J. (2011), "Cost estimation support tool for vertical high speed machines based on product characteristics and productivity requirements", International Journal of Production Economics, vol. 134, pp. 188-195.

Ravisankar, V., Balasubramanian, V. and Muralidharan, C. (2006), "Selection of welding process to fabricate butt joints of high strength aluminium alloys using analytic hierarchic process", Materials \& Design, vol. 27, no. 5, pp. 373-380.

Roy, R. (2003), "Cost engineering: why, what and how?", Decision Engineering Report Series, Cranfield University, UK.

Schreve, K. (1997), Cost estimating welded assemblies produced in batches. University of Stellenbosch, South Africa.

Shehab, E. and Abdalla, H. (2001), "Manufacturing cost modelling for concurrent product development", Robotics and Computer-Integrated Manufacturing, vol. 17, no. 4, pp. 341353.

Shehab, E. and Abdalla, H. (2002a), "A design to cost system for innovative product development", Proceedings of the Institution of Mechanical Engineers, Part B: Journal of Engineering Manufacture, vol. 216, no. 7, pp. 999-1019. 
Shehab, E. and Abdalla, H. (2002b), "An intelligent knowledge-based system for product cost modelling", The International Journal of Advanced Manufacturing Technology, vol. 19, no. 1, pp. 49-65.

Skarka, W. (2007), "Application of MOKA methodology in generative model creation using CATIA", Engineering Applications of Artificial Intelligence, vol. 20, no. 5, pp. 677-690.

Sobek, D. K. and Liker, J. K. W. A. C. (1998), "Another look at how Toyota integrates product development", Harvard Business Review, vol. 76, no. 4, pp. 36-49.

Sobek, D. K., Ward, A. C. and Liker, J. K. (1999), "Toyota's principles of set-based concurrent engineering", Sloan Management Review, vol. 40, no. 2, pp. 67-83.

Stokes, M. (2001), Managing engineering knowledge: MOKA: methodology for knowledge based engineering applications, Professional Engineering Publishing, London.

Tammineni, S. V., Rao, A. R., Scanlan, J. P., Reed, P. A. S. and Keane, A. J. (2009), "A knowledge-based system for cost modelling of aircraft gas turbines", Journal of Engineering Design, vol. 20, no. 3, pp. 289-305.

Ward, A. C. (2007), Lean product and process development, Lean Enterprises Institute Inc, Cambridge, MA, USA.

Ward, A. C., Liker, J. K., Cristiano, J. J. and Sobek, D. K. (1995), "The second Toyota paradox: How delaying decisions can make better cars faster", Sloan Management Review, vol. 36, pp. 43-61.

$\mathrm{Xu}$, J. and Zhai, T. (2008), "The small-scale resistance spot welding of refractory alloy 50Mo50Re thin sheet", JOM Journal of the Minerals, Metals and Materials Society, vol. 60, no. 7 , pp. 80-83.

Ye, J., Zhang, B. and Qi, H. (2009), "Cost estimates to guide manufacturing of composite waved beam", Materials \& Design, vol. 30, no. 3, pp. 452-458. 